\title{
In Order to Be You Have to Be: Modeling a Constructivist Approach For for Teacher Candidates
}

\author{
Hilary Brown \\ Brock University
}

\begin{abstract}
Self-study is a method of investigating the self in relation to the other in practice. As a teacher of teachers, embarking on a self-study allowed me to go beyond investigating the content I teach and required me to investigate the manner in which it needed to be taught. This paper is an analysis of the dynamics of teaching and learning that I experienced as a university instructor who taught an instructional methods course to teacher candidates. Throughout the course, the teacher candidates were immersed in a constructivist theory of learning that underpinned the instructional strategies that I modeled throughout the 20 sessions. Twenty-eight fifth-year concurrent education students participated in two separate focus group interviews on two campuses at the end of the course. This data was collected along with my weekly reflective journal. Findings indicate that through an immersion experience dissonance ensued. In spite of the inherent challenges, both the teacher candidates and I were more likely to continue to apply parts of a constructivist learning theory beyond the present and extend what we had learned, into our future teaching and learning practice. If successful, both student and instructor have the potential to create more fully developed classrooms meeting the needs of most learners.
\end{abstract}

Keywords: constructivism, immersion, self-study, theory and practice, teacher education

Hilary Brown is in the Department of Teacher Education, at Brock University, St. Catharines, Ontario Canada

Email: hbrown@brocku.ca

Brock Education, Vol. 21, No, 2, Spring 2012, pp. 36-52 


\section{Introduction}

It is well recognized that students have difficulty connecting theory to practice. Therefore, success of a constructivist teaching and learning practice not only depends on the learners' participation, but also relies on the educator's application of constructivist instruction. A constructivist educator creates a context where the learner is motivated to learn, provide meaningful content and resources, and pose relevant problems and questions at appropriate times (Wheatley, 1991; Windschitl, 2002) while connecting these resources and questions to the students' existing knowledge (Baviskar, Hartle, \& Whitney, 2009). While this sounds plausible in theory, there are certain challenges to implementing constructivist instruction, which have "proved even more difficult than many in education realize" (Windschitl, p. 131). Studies prove that translating a theory of learning into a theory of teaching when employing a constructivist approach in a classroom setting is complex (Kroll, 2004; Richardson, 2003). Although professionals in the field support constructivist ideals of learning, constructivists struggle with the matter between theory and practice. In other words, "walking the talk is often easier said than done" (Weltman, 2002, p. 62). This is what I experienced when I began teaching Foundational Methods to beginning teacher candidates as a part-time instructor. Throughout the Foundational Methods course, teacher candidates are encouraged to question assumptions of learning, teaching, and schooling while acquiring a practical understanding of, instructional strategies, and methodologies. When promoting best practice, I espoused a constructivist teaching and learning practice, but I rarely modeled this approach. This living contradiction (Whitehead, 1989) caused tension in my teaching and learning practice.

One morning, in the middle of a lecture during my first year as a university instructor, I looked across a sea of disengaged faces. I stopped talking, turned off the LCD projector, and started:

"I feel like a bit of a fraud. Here I am telling you I am a constructivist and a humanist in today's lecture on philosophical orientation, and yet I am talking at you from down here, transmitting knowledge. This does not feel right to me. I have never engaged my students this way, and yet I have resorted to a transmission mode since I entered the university setting. I have reflected upon this, and I could use the excuse that it is due to the course mandate using PowerPoint and posting my presentations electronically, or the way this room is set up with you folks sitting in the upper tier of the lecture hall so far away, or this unmovable lectern, or the big screen projecting my PowerPoint. But quite frankly, I am finding it is a lot easier preparing PowerPoint presentations than preparing centers and exploratory learning activities. I am not happy with how I am teaching. I am turning into that teacher who teaches the same content, in the same way year after year. I need to do this differently, and I need to do it better. As I understand, all of your instructors are teaching you how to teach more effectively in order for students to have a deeper, more meaningful learning experience, me included, and yet I am doing exactly what I am asking you not to do, and I am not happy about this. I am a hypocrite. I need to do things differently so you will feel empowered to do things differently. I just wanted you to know how I am feeling about what is happening right here, right now in reference to my own teaching and learning practice". The lecture hall fell silent. I was not sure what was going on in their heads at that moment. I turned the projector back on and finished my lecture.

(Brown, 2010) 
For 16 years prior to my engagement in the Faculty of Education at a Brock University, I had taught an integrated curriculum within a constructivist paradigm to Grade 7 and 8 students. I had first-hand experience of meeting the needs of most adolescent learners while utilizing a constructivist theory of learning. This study emanates from the disconnect I was experiencing as an university instructor who, in addition to constructivism, advocated both an experiential and holistic teaching and learning approach, but instead found myself resorting to a traditional lecture-style. After teaching the Foundational Methods course for three years, and in my present role as an Assistant Professor who co-ordinates Methods, I was given the opportunity to create a separate course for concurrent education students. As a result, I established a course where the students were encouraged to construct knowledge through interacting with their colleagues, with an instructor guiding their learning, and with their field placement teachers who would direct them during their teaching practicum in a school setting. It was my hope that through an immersion experience, beginning teacher candidates would attempt this approach in their own teaching and learning practice and, in turn, allow their own students to build knowledge that was meaningful to them.

In this study, I explore the dynamics of teaching and learning of concurrent education students who were immersed in a constructivist modeled approach to teaching and learning in their fifth and final practicum year. At the same time, I interweave my own decision-making processes as a teacher and researcher needing not only to espouse, but also to live, her values, and beliefs. In the first half of the paper, I discuss what constructivism is and the challenges that exist in teaching this theory of learning with the sole hope of it being practiced within the student's field placements and beyond. I discuss the role of self-study, the context of the course, and my approach to organizing and modeling a constructivist theory of learning. In the second half, I explain the method of the study, describe the data analysis, and share the lessons I learned.

\section{Constructivism}

According to Gordon (2009), "A constructivist approach to education is one in which learners actively create, interpret, and reorganize knowledge in individual ways" (p. 738). Furthermore, it is a theory that views "learning as interpretive, recursive, building process by active learners interacting with the physical and social world" (Fosnot, 1996, p. 30). Constructivism is thus an educational learning theory that has the potential to create an educational experience where learning is more about understanding and applying concepts, constructing meaning, and critically thinking about ideas and not just accumulating random information, memorizing it, and regurgitating it (Gordon, 2009). This theory is often described in contrast to a traditional transmission approach to learning where the learner is viewed as a passive receptacle being filled with pre-determined knowledge, such as a formal lecture.

Teaching should promote experiences that require students to become active, scholarly participators in the learning process (Gordon, 2009). Therefore, the personal learning theory an educator aligns with will impact how s/he "views the role of the learner, the role of the teacher, and the conditions one considers crucial for learning" (Bullard, 2003, p. 158). I am a constructivist and as a result I passionately encourage my teacher candidates to experience how a potential constructivist classroom operates. However, there are challenges in translating constructivism as a theory of learning into viable instructional strategies that will illuminate this epistemology for teacher candidates (Holt-Reynolds, 2000; Kroll, 2004; Mintrop, 2001; Richardson, 2003). 
Richardson (2003) states that the process of directly instructing student teachers to use step-by-step constructivist methods is problematic. In fact, she believes that it contradicts the learning paradigm itself. Instead, she espouses that teacher educators should conduct their classes in a constructivist manner. Mintrop (2001) echoes this sentiment by stating that as a teacher educator he knew that he needed to "model the kind of constructivist practices for student teachers that [he] wanted them to implement it the classroom" (p. 213). However, he also acknowledged that there were challenges in the implementation process sharing that he did not know how to convey to the students all the knowledge necessary to be successful while being a constructivist at the same time. Accordingly, Kroll (2004) states that when thinking about how to teach student-teachers about constructivism, a range of ideas need to be presented with the intent that students are expected to struggle and "construct for themselves an articulated vision of learning, teaching, development, and knowledge" (p. 200). In contrast to the aforementioned theorists, Holt-Reynolds (2000) argues that executing student-centered, discourse-based classes is complex and suggests that by promoting a predominantly constructivist classroom, as teacher educators we are biasing teacher candidates against a more traditional learning approach which can be just as effective for some learners.

By restructuring the concurrent Foundational Methods course in a constructivist direction I have experienced all of these struggles. Even though I have attempted to implement thoughtfully instructional strategies that promote a constructivist learning theory to beginning teacher candidates, I too, wonder if I have done it justice, while at the same time I have questioned my role in passionately promoting a constructivist classroom. This goes beyond the act of teaching for knowledge and focuses on the importance of self-understanding and connectedness in relation to both teaching and learning and also the understanding and connectedness between the instructor and the students (Korthagen cited in Loughran, 2006). In addition to restructuring the course, I recognized the need for a balanced approach to teaching and learning where incorporating direction instruction at the appropriate time is essential. However, in spite of my struggles I do believe that teachers who have content expertise and who pay careful attention to the practices they employ, such as modeling and guiding learners in a constructivist approach, have the potential to create a transformational experience for their students and also create a community of learners. Russell (1997) has described this as the "pedagogical turn" (p. 44), whereby in addition to making content knowledge decisions, the instructor has thoughtfully chosen the manner in which the content is being taught and has explicitly shared his/her intent with his/her teacher candidates.

When I experienced a disconnect between how I initially taught Foundational Methods and a constructivist approach that incorporates a balance of direct and experiential instructional strategies, I decided to reconstruct my own practice in order to meet the needs of a unique group of beginning teacher candidates. To encourage a constructivist-learning environment, I needed to foster an educational environment where teacher candidates were encouraged to be active participants and where they could interpret their own discoveries, and organize them in a way that made sense to them. To advocate this kind of teaching and learning milieu, I needed to make this pedagogical turn and be the guide that modeled this philosophy in my own practice alongside the teacher candidates as students. Reconstruction, then, in this study occurred at two levels: in my own practice, where I attempted to effect changes in how I taught; and at the level of the beginning teacher candidates, with the hopeful outcome that they would embrace all or part of this learning theory in their own practice and work with their students towards building their own knowledge. 
In other words, introducing a constructivist educational learning theory through instructor modeling and participant immersion provided a situated context (Lave \& Wenger, 1991) in which the teacher candidates could encounter a realistic and authentic learning experience that would support their field experiences (Kim \& Hannafin, 2008). The aim of this study was thus to emphasize "comprehensive understanding involving the whole person rather than 'receiving' a body of factual knowledge about the world; on activity in and with the world; and on the view that agent, activity, and the world mutually constitute each other" (Lave \& Wenger, p. 33).

\section{Self-Study}

To gather qualitative data in an educational setting, I used a self-study design including aspects of action research (LaBoskey, 2004; Mills, 2000). At the core of self-study is the selfexamination of one's own pedagogical beliefs as evidenced in one's own teaching and scholarship (Kaplan, 2006). Therefore, to "know thyself" becomes an essential goal in the teaching and learning process. When I began questioning my instructional intent while teaching beginning teacher candidates, I realized that I needed to (re)interrogate my educational philosophy and in turn (re)examine my own practice. According to LaBosky (2004), conducting research through self-study entails five essential characteristics:

1. It must be self-initiated and self-focused.

2. It must be aimed at improving teacher education.

3. It must employ multiple (mainly qualitative) methods.

4. It must be interactive at one or more stages of the process.

5. It must achieve validation through the construction, testing, sharing, and retesting of exemplars of teaching practice.

This self-study satisfied all five characteristics. First, it was self-initiated and self-focused, stemming from the disconnect I was experiencing between my elementary teaching practice in relation to my instruction at the university level. Second, one aim of this study was to determine whether teacher candidates would be more willing to employ a constructivist teaching and learning practice when in their field placements and beyond after being immersed in a course modeling a constructivist approach. Whatever the result, this would provide the data necessary to make research-driven changes to the Foundational Methods course syllabus and thereby improve teacher education.

Third, I employed qualitative methods by using a first-person account detailing what had precipitated my decision-making process in creating this course, as well as by conducting focusgroup interviews with the participants. Fourth, I was interactive at all stages of the process, from designing the course to holding weekly conferences, to writing responses to the weekly reflections, and finally to implementing the focus-group sessions.

Lastly, this is an analysis of the dynamics of teaching and learning as experienced at the end of the academic year. An extension of this study will go on to explore how a new group of fifth year teacher candidates experience a constructivist modeled teaching and learning environment. By returning to the site of the investigation, I seek to achieve a level of trustworthiness through the construction, testing, sharing, and retesting of the modeled constructivist approach to teaching and learning. The educational significance of the second study will be to document the development and articulation of the knowledge I gain in 
collaboration with the teacher candidates I work alongside as we create and implement a communally based major course assignment.

In this self-study, I incorporated aspects of action research since I was attempting to improve how the Foundational Methods course operated to improve curriculum, pedagogy, and learning (Mills, 2000). I was particularly interested in modeling a constructivist approach to teaching and learning. I also believed that the unique needs of fifth-year students would best be met through immersion in an experiential approach. However, teaching teacher candidates in this manner went beyond the traditional notion of modeling and immersion. It "involv[ed] unpacking teaching in ways that [gave] students access to the pedagogical reasoning, uncertainties and dilemmas of practice that are inherent in understanding teaching as being problematic" (Loughran, 2006, p. 6). Additionally, I was interested in learning whether Loughran's pedagogy of teacher education would encourage teacher candidates to implement it in their own teaching and learning practice.

It is my intent to illustrate how one can employ a constructivist educational learning theory by providing an authentic educational situational context (Lave \& Wenger, 1991), with the hope that teacher candidates will embrace a constructivist approach to teaching and learning when out in their field placements and beyond when they enter the profession as certified teachers.

\section{Study Context}

As the only instructor for the fifth-year Foundational Methods course, I set out to create an authentic learning experience for this distinct group of students. According to Gordon (2008):

Knowledge is attained when people come together to exchange ideas, articulate their problems from their own perspectives, and construct meanings that make sense to them. It is a process of inquiry and creation, an active and restless process that human beings undertake to make sense of themselves, the world, and, the relationships between the two. (p. 324)

With this in mind, I decided to invite the teacher candidates to become actively involved in creating the culminating task for the course so that they could "see into the teaching being experienced so that a serious examination of teaching is always a central element of practice" (Loughran, 2006, p. 11). Over the first five sessions, we collaboratively discussed how we would utilize backwards design (Wiggins \& McTighe, 2005) to develop the culminating task, including the students' choice of what the task would be. We discussed how the collaborative groups would be formed and how we would embed Cooper's (2007) assessment for learning, assessment of learning, and assessment as learning into both the evaluation protocol and the culminating task. Throughout the collaborative process, the students were not only aware of how they would be assessed and evaluated within their collaborative groups, but were also actively engaged in developing the criteria and product on which they would be assessed. The question that was ever present was would they implement this manner of teaching and learning in his/her own classroom? By implementing this option for the teacher candidates it not only allowed them to be actively involved but also illuminated for me "the complexity of teacher educators' work [which] hinges around recognizing, responding and managing the dual roles of teaching and teaching about teaching concurrently" (Loughran, p. 11). 
Culminating task decision. For their culminating task, the students chose to create and implement an integrated unit that they would pilot in their first teaching practicum. In the simulated grade team unit (SGTU) assignment, students simulated being hired at a school and were grouped with existing grade team members with whom they were hired to collaboratively teach. To create these groups, the students were divided randomly according to the grade they were assigned to teach in their field placements. What I anticipated was a simple "learning in situ" or "learning by doing" or "situated learning" opportunity resulting in a deeper, more meaningful learning experience where learning became "an integral and inseparable aspect of social practice" (Lave \& Wenger, 1991, p. 31), to be discussed in more detail below.

Weekly sessions. Each week I taught a mini-lesson, such as lesson planning, assessment and evaluation, or classroom management, to match the session topic being taught that week to the one-year Bachelor of Education students in other sections of the Foundational Methods course. For the fifth-year education students, however, many of these topics had already been covered in previous years. Because these topics were essential in building their integrated unit assignment, I needed to be reassured that they knew the content and could apply it in the SGTU assignment. Once I established that they had an in-depth understanding of the content being presented, a whole-group discussion would ensue surrounding any issues or concerns regarding the assignment that had emerged over the week between sessions. This way I could address these concerns with the entire group.

After the discussions, the grade teams divided into groups for the final hour to work on their integrated units. I sat down with each group to address their needs. One of the most common ways in which constructivism has been misunderstood is to present it as a studentcentered teaching approach with little intervention from the teacher. I sought a balance between teacher-and student-directed learning that required me to take an active role in teaching the necessary content while at the same time allowing the teacher candidates to infuse what they knew into the learning process (Gordon, 2009). Another misconception surrounding constructivism is that teachers require students to teach themselves (Gordon, 2009). Although it is a constructivist notion to encourage students to create their own interpretations of the text, it is not the same as leaving them to learn it on their own. Therefore, I was present taking an active role while the groups collaborated on their independent units. I was continually taking part in dialogues with students and providing content expertise.

At the end of each session, we reconvened for 5 minutes as an entire class. At this time the recorder handed in a folder with reflections, detailing what had been accomplished that session. In turn, I provided written feedback so that I could provide assessment for learning each week. My weekly feedback allowed the students to gain first-hand experience immersed in Cooper's (2007) model of assessment for learning, since many students had only been exposed to the theory and not its practical application. The cycle of my feedback, followed by the teacher candidate's consideration of it, was vital for them to understand fully how assessment for learning both looked and felt.

In summary, the final assignment for the Foundational Methods course was collaboratively developed, negotiated, and implemented through exchanging ideas and constructing meaning between the students and me. As a result of this engagement, the students were explicitly guided in a modeled constructivist approach to teaching and learning, with the opportunity to put theory into practice thereupon through creating a collaborative unit that they 
could implement in their first teaching block. In the remainder of this paper, I describe the methodology and discuss the lessons learned from immersing teacher candidates in a constructivist teaching and learning approach.

\section{Study}

I sought to better understand my practice in order to improve teacher candidates' understanding and use of constructivism in teaching. Engaging in self-study (LaBoskey, 2004), allowed me to develop a deeper understanding of my own teaching practice and, with this knowledge, explore how I, as a constructivist teacher, could effect positive change ultimately aimed at improving teacher education through the teaching of Foundational Methods to fifth-year students. In short, I (a) collected data from students to find out how effective my constructivist approach to teaching and learning was, and (b) this fed into my reflections and process of developing a pedagogy of teaching and in doing so (c) I theorized my practice based on the results to become more effective. According to Loughran (2006) theorizing our practice so that we are aware of not only what we know but that we can also articulate it to our students through our teaching assisted me in answering the fundamental question driving this study which was whether immersion in a constructivist-modeled course would encourage teacher candidates to implement this approach in their field placements and beyond.

\section{Method}

All fifth-year teacher candidates were invited to share both their positive and negative experiences when immersed in a constructivist-modeled course by participating in a focus-group interview before going out into the field for their final teaching placement. This method allowed me to gather a shared understanding (Creswell, 2008) of two groups of fifth-year teacher education candidates on two campuses since their time availability was limited. A focus-group session allowed me to maximize the narrow time frame between our final class and their final teaching practicum.

Recruitment. After all assignments had been graded, I invited the teacher candidates to participate. Nineteen of 55 on one campus agreed to participate in a focus group. Nine of 22 students on the other campus participated in a second group. I facilitated a semi-structured interview with five key guiding questions. This open-ended format allowed for topics to emerge from the participants.

Data processing and analysis. My analysis began with the transcription of the audio recording. Throughout this process, I had a chance to complete a general but also an intimate review of all information (Creswell, 1998). As I typed the participants' words, I began to identify issues, factors, themes, and items that came up repeatedly from the data. While immersed in the transcribing phase, I created memos reflecting my intuition of the data (Stern \& Porr, 2011) that helped me to begin to make sense of it all. After the transcription was complete, I sent out a copy to the participants for member checking. While continuing to reread the entire data collection, I absorbed and backtracked through the textual data and created additional memos as I continuously spiraled back (Creswell, 1998) on the data to make meaning out of the participants' experience. 
As I coded and categorized the data (Creswell, 1998) consistent themes emerged. Often, a single response fell into multiple categories. To convey the intricacy of the response the data was coloured during the axial coding phase. By reassembling the data in a new way after open coding (Creswell, 1998, 2008), I was able to further reduce the data into more manageable chunks. As Creswell $(1998,2008)$ observed, "Data analysis is not off the shelf; rather it is custom built" (p. 42); therefore, through data reduction the data became more controllable (Berg, 2004). With legend titles created that matched the categories I identified six themes.

The profusion of color-coded pages of data was then transferred into a spreadsheet to make it even more manageable. By transforming the data (Berg, 2004) and listing the themes at the top of six columns, I was able to move each section of text to the appropriate columns. Some data were included in multiple columns. This presentation of the data enabled me to focus on each separately while keeping in mind patterns across the data set (Berg, 2004).

In the final phase of the analysis, selective coding was used. I asked, myself "What is the hingepin holding the [students'] stories together? What is the point of convergence?" (Stern \& Porr, 2011, pp. 66-67). I looked for the common issues, concerns, and recurring problems that would best represent the students' experience in a modeled constructivist classroom and isolated each one, along with the "aha!" moments, and focused my coding here. Then I asked, "What are the labeled codes and conceptual categories connected to this hingepin?" (Stern \& Porr, p. 67). This allowed me to further identify those specific patterns in behavior that either stifled or allowed the students to embrace a constructivist classroom.

\section{Lessons Learned}

What I gleaned from the two focus-group interviews on both campuses reaffirmed some broad perspectives on teaching and learning. First, the instructor plays a central role when implementing a constructivist approach by honouring the prior knowledge and experiences of his/her students and extending what s/he teaches from the point of introduction onwards. Second, having students authentically reflect on their own practice, adds meaning to the process the students undergo. Last, dissonance is an important part of the learning process if learning for transformation is to occur. All of these broad perspectives on teaching and learning have been well established in the literature on educational theory (e.g. Brookfield, 1995; 2006; Grennon Brooks \& Brooks, 1993; Mezirow and Associates, 2000; Schön, 1987). However, what has not been well documented is how a university instructor acts in response to how these broad perspectives play out while a group of students is interpreting and learning in a constructivistlearning environment. In this section, I will share the lessons I have learned while conducting this self-study. It is my hope that this will help teacher educators implement a constructivistmodeled approach to teaching and learning with his/her teacher candidates and perhaps even conduct an action self-study of his/her own in order to critically reflect upon his/her own practice so that s/he can share his/her learning with other teachers educators.

\section{Lesson One: Instructor Risk Taking}

There is a disconnect between the theory I espouse as best practice, which is a well-balanced approach to constructivist teaching and learning which includes implementing direct instruction when necessary, and what our teacher candidates experience in their field placements, which is predominantly traditional direct instructional teaching practices. For example, one focus-group 
participant, when discussing her own evaluation of the integrated unit, stated that she had chosen to include the math unit she was teaching in her field placement. In her unit there was no balanced approach. She had made no attempt to include hands-on learning tasks using manipulatives in her lessons; instead, the unit took the shape of formal lessons using direct instruction followed by a silent independent work period completing assigned questions from the textbook. My evaluation of her work, based on the evaluation rubric the students had created and of which she was a part, reflected the lack of ingenuity on her part in integrating current math practices into her lesson. She had succumbed to a formal instructional approach during her field placement while concomitantly being involved in creating a collaborative integrated unit for her teaching block in the Foundational Methods course. The disconnect between theory and practice was clear; however, she had not recognized this limitation in her own practice. Instead she chose to mirror the way her field placement teacher taught, as she later explained:

I actually used the section of my unit in my field placement and one of the responses I got back in the assessment was that, it was math, that it was rote right out of the textbook, but that is what my field placement teacher expected because this is how she taught. The way that my field placement teacher taught, that's not me, but I had to teach that way and so that is what came through my unit.

In spite of 4 years of educational theory advocating a constructivist approach to teaching and learning, she surrendered to a practice using a direct instruction approach, a philosophy she did not support.

What I learned from this experience is that in the past, I had been contributing to creating passive, teacher candidates who simply applied traditional methods by rote. That is, students come into their final year with many years observing what they deem as best practice based on what they have experienced in their own years of informal and silent observation as students throughout their educational careers. Lortie (2002) refers to this as an apprenticeship of observation. What this lesson taught me, was that I need to take risks, and continue to reconstruct my teaching practice, such as modeling a constructivist approach to teaching and learning, and in doing so disrupt the status quo so teacher candidates can experience a different kind learning environment so that they can broaden their practical repertoire of teaching and learning strategies.

If teacher educators feel that the theory they are espousing is not translating into practice when teacher candidates are in their field placements then this study may provide teacher educators with the framework to reconstruct their practice. This in turn may create a learning environment where both the teacher educator and the teacher candidates can implement a constructivist-modeled approach to teaching and learning which may narrow the gap between theory and practice.

\section{Lesson Two: With Risk Comes Dissonance}

There is no doubt that when learners are led into the unknown dissonance ensues (Kroll, 2004; Mintrop, 2001; Richardson 2003). How the participants felt going through a constructivistmodeled course became an integral part of the experience. In their words, they were "thrown out of their comfort zone," "confused," and "uncomfortable". There was "a lot of resistance with this style", and "moaning and grumbling", and students asking, "What am I doing here?" When 
expressing their frustration with the course, they often juxtaposed past learning experiences to make a comparison to their present experience. For example, in the past, they had been taught what to think and what to say through formal instruction. Words such as "conditioned," "programmed," "preached to," and "indoctrinated" were used to describe previous learning moments. As one participant stated, "We know what the prof wants, we know the drill." Another concurred, stating "instructors want us to know everything in accordance to them." It was a milieu in which they felt comfortable, and they mentioned they had expected Foundational Methods to be organized in the same fashion, with a "direct approach to teaching and learning via a Power Point presentation." Perhaps this is why they felt "thrown into the unknown," and "experiencing a jolt to the system" which encouraged them to construct meaning that made sense to them.

I, too, experienced weeks of discontent and restlessness while teacher candidates were disenchanted with the process. Being greeted with silence-students would not even utter "good morning" - I found this bewildering. I spent more than half the course - 4 months — struggling to make inroads with this group. I experienced a wall of resistance from the participants, who initially were unwilling to shake loose from their preconceived notions of how one learns in a university setting, leaving me feeling defeated and unsuccessful in the delivery and implementation of the course.

The lesson I learned from our shared dissonance that both the students and I felt was that learning in collaboration with the teacher candidates through both the challenging and the transformational moments proved to be worthwhile. We just needed time to absorb fully what each other was experiencing before we could embrace a positive shift in attitude and appreciation for the collaborative learning process.

It was not until just after the midway point that I noted in my journal that a shift had occurred in the group's attitude. A couple of participants stated that when they realized that I was modeling the theory they had learned over the past 4 years, they experienced an "aha moment" that resulted in a transformational experience for both of them. Because this group had moved through the teacher education program as a cohort over a 5-year period, they knew each other very well. Perhaps, as this group had been together for five-years, this incited a ripple effect throughout the cohort.

By January of the academic year, the momentum had shifted and a more positive attitude began to expand and extend across the group, as most of the students became more open to a constructivist approach. But even though the cognitive dissonance experienced both by me and by the students was undeniable, the lesson I learned was that it was necessary for me to experience cognitive dissonance myself as part of the process. In a study by a teacher educator and a student teacher Russell and Bullock (cited in Loughran, 2006, p. 7), note, "unpacking a teacher educator's practice can be a powerful way of learning about one's own teaching. And it does so by creating the impetus for pursuing the necessary risk-taking that is so important in shaping learning" (p. 7). It seemed that my risk and dissonance that ensued helped me to identify with the students' experience of struggle. The discontent the students experienced when I would not tell them what to think, as well as working through my own struggles attempting to find ways to reach the group, was worth the discomfort that both the students and I felt. Knowing that I will probably face a group of resistant fifth-year students again in the next academic year is the challenge I face as I prepare to model this approach to the next group of teacher candidates. Knowing what may happen does not make it any easier, but as Freire (1997) states: "Without a vision for tomorrow, hope is impossible" (p. 45). 
Teachers of teachers attempting this approach with teacher candidates may undergo moments of utter joy and amazement alongside moments of utter despair and frustration, both are worthwhile and a cause for both critical and self-reflection as teacher educators position themselves to improve their practice as teacher educators.

\section{Lesson Three: To Continue To Encourage Teacher Candidates To Take Risks}

Teacher candidates who are willing to take risks, travel outside their comfort zone, and extend themselves intellectually, socially, emotionally, and spiritually appear to embrace a constructivist approach more readily than those who are not risk takers and who need to continue on a safer, more structured, and defined path. As one participant surmised during the focus group:

I think the general theme of what we have just been talking about is risk versus reward. It may be scary to implement something that you are not comfortable with or something that requires a lot of front-end loading, but I think we all realize the reward that we got out of it and what our students will get out of it.

This participant embraced what she learned and is now projecting this into her future profession as a teacher practitioner.

As another example, one teacher candidate with a challenging intermediate-homeroom field placement teaching assignment, asked me for advice on how she could implement and facilitate a circle meeting into a Catholic school curriculum. I shared detailed information with her on how to do so. While the field placement teacher was skeptical she allowed the teacher candidate to explore this intrapersonal curriculum. The teacher candidate shared her experience during the focus group:

I found that I was actually able to do the sharing circle in my class and that was an invaluable experience. It really blew away all the teachers in my grade group as well as my field placement teacher, who if you remember, I struggled to like at first. You were saying to implement it, but since I was a guest in her classroom, to implement it in her classroom was a struggle at first, but it ended up being an incredible experience. So in some respects I do feel comfortable to implement some of things that I have learned from this classroom and I feel it really changed my experience. I also know it changed other teachers' viewpoints on students, and more importantly, it changed the students that I worked with, and that was one of the most touching and heartfelt experiences I have ever had in a classroom, and it reminded me of the real reason I am a teacher.

The lesson I learned from the risk versus reward analogy is that it is necessary for students to be immersed in a course where the learning requires them to be active rather than passive, and where constructing one's own interpretations of the lived experience is essential. In short, I need to provide challenging experiences in the classroom so students can extend themselves and take risks grounded in practice, not just grounded in theory, as they potentially transfer this experience into their field placements and beyond into their own classroom practice.

A teacher educator accepting the prospect that cognitive dissonance may be present when modeling a constructivist approach with teacher candidates, may better prepare him/herself for this possibility unlike what I experienced. However, knowing that cognitive dissonance is 
necessary in order for transformational learning to occur allows teacher educators to embrace this likelihood in an optimistic manner and that they can come out the other side with deeper understandings.

\section{Lesson Four: In Order To Be, You Have To Be}

If I want students to become constructivists, I have to be a constructivist myself; if I want to continue to improve my own teaching and learning practice, I have to take risks, and accept constructive criticism in order to build on my previous knowledge.

At the beginning of the course, I took the risk of inviting students to become active creators of the culminating task. I was open and receptive to whatever they proposed regardless of my bias towards any assignment they may have suggested. I stepped outside my personal comfort zone and trusted the process. I firmly believed that building on concurrent education student's prior knowledge was sound pedagogy and brought meaning to their practice as beginning teachers as well. In addition to the initial stage of the course, there was a duration of time in the process when the teacher candidates found themselves in turmoil over what they deemed as being given no direction, since I did not tell them what, how, and when to think. At this juncture, I had to remind myself that as a constructivist I needed to take risks and that the risk is worth the reward. I needed to remain steadfast and trust the process in order to move the teacher candidates and myself; through the dissonance we were experiencing.

As a constructivist willing to take risks, I invited students to be honest and authentic learners, it followed that I should embrace constructive criticism and the suggested improvements that are a natural result of the invitation. I needed to be open and receptive to the constructive criticism that the students willingly shared and more importantly I needed to take action and implement the suggested improvements where feasible.

In summary, I learned that I have to be a constructivist and believe in the process myself as a learner in order to guide teacher candidates through it. If I had not previously experienced a constructivist approach to teaching and learning, then I may have been tempted to resort to simply telling the teacher candidates what to do when they became frustrated instead of continuing to guide their learning process. Near the end of the course many teacher candidates came to a similar realization themselves. They stated that they were glad they experienced constructivist theory in practice which allowed them to begin to understand the struggles their own students may face when they approach their own practice in a constructivist way.

For teacher educators to improve what they do, perhaps attempting a practical constructivistmodeled approach to teaching and learning will offer them a fresh way of approaching their practice while meeting the needs of teacher education students who are well versed in educational theory but need more practical experience. In entering into this new manner of teaching, teacher educators have the opportunity to engage in dialogue with teacher candidates about not only what is being taught but at the same time,

Questioning, examining and learning about the way in which it is actually being taught: asking questions about the nature of the teaching; the influence of the practice on the subsequent learning (or lack thereof); the manner in which the teaching has been constructed 
and is being portrayed; how the teaching-learning environment has been created and so on. (Loughran, 2006, p. 4)

This may open a door for teacher educators to develop their own professional knowledge and practice.

\section{Implications}

Reconstructing my practice to incorporate a constructivist learning theory brought me one step closer towards narrowing the gap between the textbook theory of constructivism and the practical application of constructivism. Immersing students in constructivism enabled me to create an environment where understanding and applying concepts, constructing meaning and critically thinking about ideas were achieved. I discovered that by going through an immersion process teacher candidates gained the confidence to implement a constructivist approach or parts of the approach in their own teaching and learning practice. I was encouraged that many will implement it when out in their field placements as they begin to live fully their values and beliefs while honing their craft.

If I am to improve my practice as a teacher educator, I must continue to push myself out of my comfort zone and promote experiences that require students to become active participators in the learning process. I must provide the necessary scaffolding for all parties to succeed when embarking on a risk-taking endeavor such as the immersion process described in this article. By the same token the teacher candidates also have to work through the resolved and unresolved dissonance they have experienced and make sense of it in terms of their own teaching and learning practice. After all, transformation can only occur if it is carried out with the people, not for them (Freire, 1970).

I believe that if teacher educators are willing to open this door and consider reconstructing how they are teaching teacher candidates, that the active application of a constructivist learning theory into one's practice will make the learning environment richer, give it context, and bring it alive in spite of the risk of becoming unpopular (Hart, 2009). It plants the seeds for potential transformational learning to take place.

In the end, if teacher educators are successful working through a constructivist model such as the one described here, teacher candidates learn in an educational milieu that honors their unique learning profiles and a more fully developed classroom environment emerges that meets the needs of most learners. Teacher educators who experiment with teaching teachers in this manner help support a growing knowledge of teaching and learning by articulating a pedagogy of teacher education that challenges teaching as telling by enhancing teaching for understanding (Loughran, 2006). Both endeavours, teacher educators' teaching about teaching and teacher candidates' learning about teaching, are equally important and need to be considered when analyzing the dynamics of teaching and learning. 


\section{References}

Baviskar, S. N., Hartle, R. T., \& Whitney, T. (2009). Essential criteria to characterize constructivist teaching: Derived from a review of the literature and applied to five constructivist-teaching method articles. International Journal of Science Education, 31(4), 541-550. doi:10.1080/09500690701731121

Berg, B. L. (2004). Qualitative research methods for the social sciences (5th ed.). New York, NY: Pearson.

Brookfield, S. D. (1995). Becoming a critically reflective teacher. San Francisco: Jossey-Bass.

Brookfield, S. D. (2006). The skillful teacher: On technique, trust, and responsiveness in the classroom (2nd ed.). San Francisco: Jossey-Bass.

Brown, H. (2010). I must walk through the gate: An ontological necessity. Unpublished PhD, Faculty of Education, Brock University, St. Catharines.

Cooper, D. (2007). Talk about assessment: Strategies and tools to improve learning. Toronto, ON: Thomson Nelson.

Creswell, J. (1998). Qualitative inquiry and research design: Choosing among five traditions. Thousand Oaks, CA: Sage.

Creswell, J. W. (2008). Educational research: Planning, conducting, and evaluating quantitative and qualitative research (3rd ed.). Upper Saddle River, NJ: Pearson.

Fosnot, C. T. (1996). Constructivism: A psychological theory of learning. In C. T. Fosnot (Ed.), Constructivism: Theory, perspectives, and practice (pp. 8-33). New York: Teachers College Press.

Freire, P. (1970). Pedagogy of the oppressed. New York: Continuum.

Freire, P. (1997). Pedagogy of the heart. New York, NY: Continuum Pub Group.

Gordon, M. (2008). Between constructivism and connectedness. Journal of Teacher Education, 59(4), 322-332. doi:10.1177/0022487108321379

Gordon, M. (2009). The misuses and effective uses of constructivist teaching. Teachers and Teaching: Theory and Practice, 15(6), 737-746. doi: 10.1080/13540600903357058

Grennon Brooks, J., \& Brooks, M. G. (1993). In search for understanding: The case for constructivist classrooms. Alexandria, VA: Association for Supervision and Curriculum Development. 
Hart, T. (2009). From information to transformation: Education of the evolution of consciousness. New York: Peter Lang.

Holt-Reynolds, D. (2000). What does the teacher do? Constructivist pedagogies and prospective teachers' beliefs about the role of a teacher. Teaching and Teacher Education 16, 21-32.

Kaplan, J. (2006). Self-study of teacher education practices: Merging the affective and the effective in classroom methodology. Proceedings of the Sixth International Conference on Self-Study of Teacher Education Practices (pp. 138-142). Herstmonceux Castle, East Sussex, UK.

Kim, H., \& Hannafin, M. J. (2008). Situated case-based knowledge: An emerging framework for prospective teacher learning. Teaching and Teacher Education, 24, 1837-1845. doi:10.1016/j.tate.2008.02.025

Kroll, L. R. (2004). Constructing constructivism: how student-teachers construct ideas of development, knowledge, learning, and teaching. Teachers and Teaching: Theory and Practice, 10(2), 199-221. doi: 10.1080/1354060042000188035

LaBoskey, V. K. (2004). Moving the methodology of self-study research and practice forward: Challenges and opportunities. In J. J. Loughran, M. L. Hamilton, V. K. LaBoskey, \& T. Russell (Eds.), International handbook of self-study of teaching and teacher education practices (pp. 1169-1184). Dordrecht, The Netherlands: Kluwer Academic.

Lave, J., \& Wenger, E. (1991). Situated learning: Legitimate peripheral participation. Cambridge, UK: Cambridge University Press.

Loughran, J. (2006). Developing a pedagogy of teacher education: Understanding teaching and learning about teaching. New York: Routledge.

Lortie, D. C. (2002). Schoolteacher: A sociological study, with a new preface. Chicago, IL: The University of Chicago Press.

Mezirow, J., \& Associates. (2000). Learning as transformation: Critical perspectives on a theory in progress. San Francisco: Jossey-Bass.

Miller, J. P. (2007). The holistic curriculum (2nd ed.). Toronto, ON: University of Toronto Press.

Mills, G. E. (2000). Action research: A guide for the teacher researcher (2nd ed.). Upper Saddle River, NJ: Merrill/Prentice Hall.

Mintrop, H. (2001). Educating students to teach in a constructivist way - Can it all be done? Teachers. College Record Volume, 103(2), 207-239.

Richardson, V. (2003). Constructivist pedagogy. Teachers College Record, 105(9), 1623-1640. 
Russell, T. (1997). Teaching teachers: How I teach IS the message. In J. Loughran \& T. Russell (Eds.), Teaching about teaching: Purpose, passion, and pedagogy (pp. 32-47). London: Farmer Press.

Schön, D. (1987). Educating the reflective practitioner. San Francisco: Jossey-Bass.

Stern, P., \& Porr, C. J. (2011). Essentials of accessible grounded theory. Walnut Creek, CA: Left Coast Press.

Weltman, B. (2002). Praxis imperfect: John Goodlad and the social reconstructionist tradition. Educational Studies, 33(1), 61-83.

Wheatley, G. H. (1991). Constructivist perspectives on science and mathematics learning. Science Education 75(1), 9-21.

Whitehead, J. (1989). Creating a living educational theory from questions of the kind, "How do I improve my practice?" Cambridge Journal of Education, 19(1), 41-52.

Wiggins, G., \& McTighe, J. (2005). Understanding by design (2nd ed.). Alexandria, VA: Association for Supervision and Curriculum Development.

Windschitl, M. (2002). Framing constructivism in practice as the negotiation of dilemmas: An analysis of the conceptual, pedagogical, cultural, and political challenges facing teachers. Review of Educational Research, 72(2), 131-175. 